\title{
Met Dieric Bouts: investigaciones en torno al contrapunto cinematográfico
}

\author{
Santiago Rubín de Celis Pastor*
}

Resumo: Apresenta-se uma análise estrutural de Met Dieric Bouts (1975), de André Delvaux, centrada na sua concepção sonora, que segue um esquema de construção derivado das estruturas rítmicas utilizadas como contraponto das obras de Guillame Dufay e Guillame de Machault.

Palavras-chave: contraponto; estrutura musical; trilha sonora; André Delvaux; ensaio cinematográfico.

Resumen: Un análisis estructural del film Met Dieric Bouts (1975) de André Delvaux centrado en su concepción sonora, que sigue un esquema de construcción derivado de las estructuras rítmicas utilizadas en el contrapunto en las obras de Guillame Dufay y Guillame de Machault.

Palabras clave: contrapunto; estructura musical; banda de sonido; André Delvaux; ensayo cinematográfico.

\begin{abstract}
A structural analysis of André Delvaux's Met Dieric Bouts (1975) focused on his sonorous conception, which follows a construction scheme derived from the rhythmic structures used in the counterpoint in the works of Guillame Dufay and Guillame de Machault.

Keywords: counterpoint; musical structure; soundtrack; André Delvaux; cinematographic essay.

Résumé : Analyse structurale de Met Dieric Bouts d'André Delvaux (1975) portant sur sa conception sonore, qui suit un schéma de construction dérivé des structures rythmiques utilisées dans le contrepoint dans les travaux de Guillaume Dufay et Guillaume de Machault.

Mots-clés : contrepoint ; structure musicale ; bande-son ; André Delvaux ; essai cinématographique.
\end{abstract}

* Istituto Europeo di Design Madrid, Dep. Visual Communication. 28004, Madrid, España. E-mail: gatopirrakas@hotmail.com

Sumisión del artículo: 12 de enero de 2017. Notificación de aceptación: 22 de julio de 2017.

Doc On-line, n. 22, setembro de 2017, www.doc.ubi.pt, pp. 185-197. 
A lo largo del año 1975, Bélgica celebraba el quinto centenario de la muerte de Dirk Bouts, ${ }^{1}$ pintor holandés nacido en Haarlem pero que - según documentó Karel van Mander ${ }^{2}$ - ya a mediados del siglo XV se había instalado en Lovaina, ${ }^{3}$ lugar donde se casó, trabajó y donde murió. Para conmemorar este aniversario, la Belgische Radio en Televisie (BRT), la televisión pública belga, y el Ministerio de Cultura Flamenca (Ministère Flamande de la Culture) proyectaron producir un mediometraje sobre el pintor y contactaron con el cineasta André Delvaux, seguramente el realizador más prestigioso internacionalmente del país, para realizarlo. Sería su primer trabajo en dos años, desde que estrenase Belle (Belle, 1973), coincidiendo con la XXVI ${ }^{\mathrm{a}}$ edición del festival de cine de Cannes, en la sección a concurso. Lo que no evitó que en un principio el director rechazara el encargo, pensando que el hecho de aceptar eso que Georges Franju denominó expresivamente "filmes culturales de propaganda", ${ }^{4}$ le alejaría del mercado de producción de largometrajes de ficción. Albergaba también serias dudas, debido a lo limitado de su futura distribución (un producto audiovisual destinado exclusivamente a la televisión), de que la película le aportase demasiado prestigio dentro de la profesión. Sin embargo, tras sus cuatro primeros largometrajes, aplaudidos por la crítica especializada y galardonados en diversos festivales internacionales, que le habían granjeado la condición de figura señalada del cine belga de ficción, Delvaux empezaba a considerar algo que confesaría solo algunos años más tarde ${ }^{5}$ : que las posibilidades expresivas, estructurales y temáticas de ese realismo mágico cinematográfico, que había desarrollado merced a títulos como El hombre del cráneo rasurado (De man die zijn haar kort liet knippen, 1965), Una noche, un tren (Un soir, un train, 1968) o Cita en Bray (Rendez-vous à Bray, 1970), estuviesen próximas a apurarse. "Serían las circunstancias las que me iban a permitir transgredir ese sistema [el realismo mágico], al aceptar un encargo en el que se unían la pintura, la literatura y el cine". ${ }^{6}$ Así, con Met Dieric Bouts (1975) inauguraría un nuevo trayecto dentro de su filmografía, lo que Dirck.

1. El nombre del pintor aparece a veces también escrito con las grafías Dieric, Dierick y

2. Como atestigua su Het Schilder-boeck ("Libro de pintores" o "Libro de la pintura"), publicado por Passchier Wesbusch en Haarlem 1604, que describe la vida y obra de más de doscientos cincuenta pintores flamencos.

3. Fue documentado por primera vez en Lovaina hacia 1457 y se convirtió en pintor de la ciudad desde 1472 en adelante. 24.

4. Brumagne, M-M. (1977), Franju. Impressions et aveux, Lausana: L'Age d'Homme, p.

5. Ver Sojcher, F. (2005), André Delvaux, le cinéma ou l'art des rencontres, París: Seuil/Archimbaud, p. 56.

6. Delvaux, A. (2003), Un trayecto de cineasta. En LARA, F. (Ed.), Doce miradas sobre el cine europeo (el autor y su obra), Valladolid: Junta de Castilla y León, p. 84. 
los estudiosos Borgomano y Nysenholc ${ }^{7}$ han dado en denominar filmes de investigación ("films de recherche"). Este grupo de películas incluye, además del citado mediometraje que nos ocupa, los largos To Woody Allen from Europe with love (1981) y Babel Opera ou La répétition de Don Juan (1985) y, a partir de un ejercicio que combina a menudo el cine-ensayo con dispositivos propios del cine de ficción, reflexiona sobre las condiciones de la creación cinematográfica y sus relaciones con otros lenguajes expresivos - como los de la pintura o la música - así como sobre el oficio del cineasta en tanto que praxis con el espejo de un Woody Allen inmerso en el rodaje de Recuerdos (Stardust Memories, 1980) - a través de diversas problemáticas asociadas a labores de puesta en escena o de edición.

\section{Con Dieric Bouts}

Ya desde su mismo título, significativamente Met Dieric Bouts, Delvaux e Ivo Michiels, su co-guionista, despejan una incógnita. Después de la última gran guerra, cineastas como Henri Storck, Alain Resnais, Luciano Emmer o Pierre Kast llevaron a cabo una serie de investigaciones cinematográficas en torno al cine documental y la pintura. A propósito de ellas Bazin escribió su célebre ensayo "Pintura y cine", ${ }^{8}$ en el que exponía cómo este paradigma dominante del "film de arte" - con un encuadre que no incluye la totalidad del cuadro, privado de su marco, esto es, de sus límites; descomponiendo la pintura a partir de un montaje fragmentario que le priva de su continuidad; creando una narrativa externa a la de la obra pintada; etc. - destruía por completo la unidad temporal y el espacio pictóricos. Una operación que "desnaturaliza radicalmente la manera de ser de la pintura", ${ }^{9}$ haciéndola "soluble" (Bazin, 1990: 213) al aparato cinematográfico anteriormente expuesto de manera sinóptica. Estas películas documentales, partiendo de la biografía del artista - un período concreto dentro de su obra, la gestación de una de sus obras maestras, etc. -, desglosada en el comentario que las acompaña, elaboran un "repaso" visual gracias a los fragmentos de sus pinturas que nos muestran sus imágenes. El resultado - como en los célebres Le monde de Paul Delvaux (1946), Van Gogh (1948), Il paraiso perduto (1948) o Les desastres de la guerre (1951), por citar algunos ejemplos - es una mera ilustración divulgativa y fragmentaria de los cuadros de Delvaux, Van Gogh, Hyeronimus Bosch o Goya. Una ilustración que, según Aumont (1997: 80), se apoya fundamentalmente en tres operacio-

7. Ver Borgomano, L. \& Nysenholc, A. (1988), André Delvaux. Une æuuvre, un film: L'Euvre au noir, Klincksieck: Éditions Labor-Méridiens, pp. 22-31.

8. Incluido en Bazin, A. (1990), ¿Qué es el cine?, Madrid: Rialp, pp.211-216.

9. Bazin, A. (1990), Op. cit. p. 213. 
nes sistemáticas: a) una diegetización de la pintura, es decir, el hecho de que cada cuadro, un mundo ficcional completo, sea descompuesto en sucesivos planos/episodios destruyendo su unidad; b) una narratización que se sirve de esos fragmentos (a veces, incluso, de cuadros distintos), a través del montaje, creando una falsa continuidad pictórica, para crear un nuevo "relato visual" pictórico y c) una psicologización que, derivada de las dos anteriores, busca penetrar en la intencionalidad del pintor para explicar sus obras. Como consecuencia de las mismas, en dichas películas se evacua, se vacía, precisamente "lo que en ellas es pintura - el toque, la pasta, el color, la composición - para convertirlas en diégesis, en relato, en film". ${ }^{10}$ Se trata de una cinematización de un lenguaje, el de la pintura, a través del lenguaje fílmico.

$\mathrm{Al}$ aceptar Delvaux el encargo de realizar la película sobre Bouts, la primera que hubo de abordar fue, precisamente, la cuestión de qué tipo de film quería concebir sobre el pintor. Lejos de este tipo de "cinematización de la pintura" propia del documental sobre arte dominante, el autor de El hombre del cráneo rasurado pretendía, sin recurrir a aspectos biográficos, indagar en la figura del pintor a través de algunas de sus huellas visibles (sus pinturas, los lugares en los que habitó, etc.). Indicios que les sirven a Delvaux y Michiels para, más allá de la pintura, realizar una meditación sobre las relaciones del pintor con la cultura flamenca e, incluso, con ellos mismos. Retomando ese Met Dieric Bouts del título, es decir, "Con Dieric Bouts", éste nos indica el papel de guía que desempeñará el pintor, una huella a partir de la cual rastrearse. "Hemos construido la película - admitía el propio Delvaux - diciéndonos que no la íbamos a hacer sobre Dieric Bouts, sino que la íbamos a hacer con Dieric Bouts". ${ }^{11}$ Una idea que se impone desde los propios títulos de crédito. En ellos, se superponen los contratos que legalizan la realización de dos encargos bien distintos pero entrelazados estrechamente: el panel central del Retablo del Santo Sacramento, pintado por Bouts en 1464 con destino a la iglesia de Sint-Pieterskerk (San Pedro de Lovaina), y «un film sonoro y en color dedicado a Dieric Bouts», por parte de Delvaux. En el centro del retablo (como escuchamos gracias a la lectura del contrato) deberá figurar «la última cena de Nuestro Señor Jesucristo en compañía de sus doce apóstoles». De manera análoga, toda la película se construye, poniendo en escena esa última cena de Bouts, a partir de la identificación de sus creadores, Delvaux y Michiels, con el pintor y sus obras. Una afinidad que, según el realizador, va aún más allá, dado que la película es también "una manera de reencontrar nuestras raíces flamencas a través de la pintura y de nuestras respectivas vivencias... Ivo Michiels, la

10. Aumont, J. (1997), El ojo interminable. Cine y pintura, Barcelona: Paidós, p. 81.

11. Declaraciones del cineasta recogidas en el V.V.A.A. (2001), André Delvaux, Madrid: Filmoteca Española, p. 6. 
muerte de su madre, yo, la de mis abuelos y mi padre, que fueron enterrados en Lovaina al igual que Bouts" ${ }^{12}$. Lovaina es, evidentemente, el territorio de esa coincidencia, una suerte de país - unidad vivencial, lingüística, cultural común que no es "sino un espacio interior, una región del alma", ${ }^{13}$ basada en la experiencia más que en un lugar físico determinado.
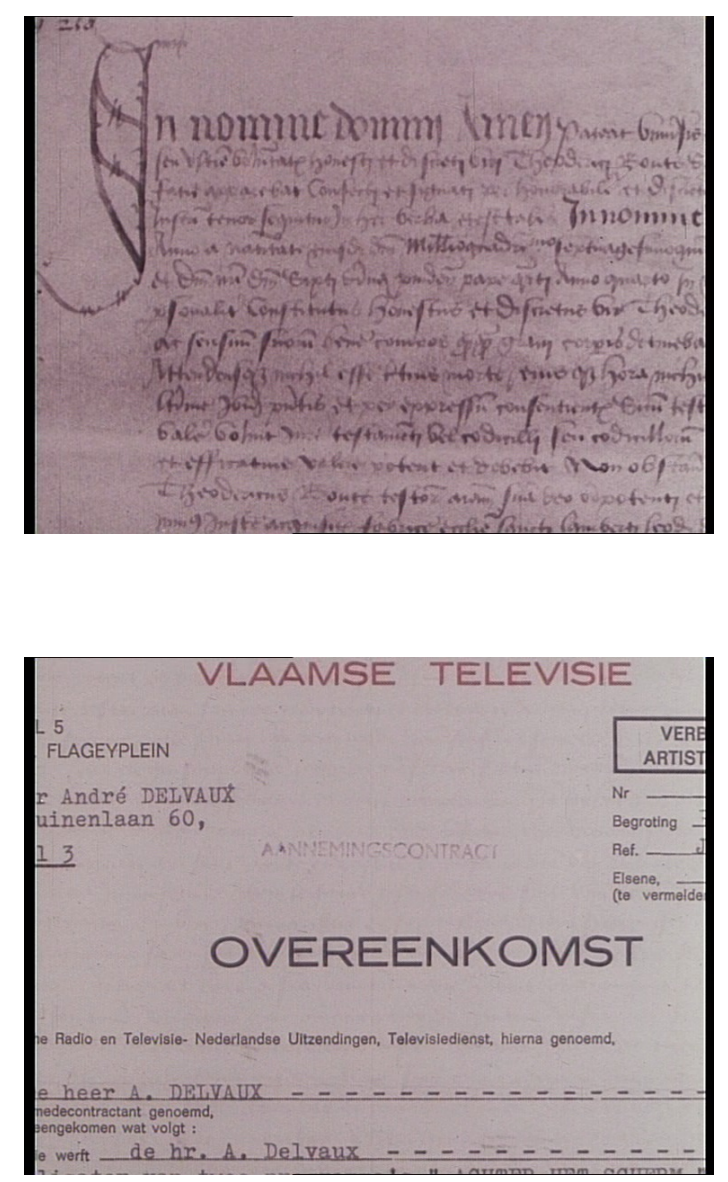

Figs. 1 y 2. Los contratos para la realización de dos encargos, el panel central del Retablo del Santo Sacramento, pintado por Bouts, y «un film sonoro y en color dedicado a Dieric Bouts», por parte de Delvaux.

De la mano del pintor, siguiendo su rastro, los autores se lanzan en pos de una exploración, de una búsqueda. Met Dieric Bouts no es una película de arte,

12. Sojcher, F. (2005), Op. cit., p. 56.

13. Delvaux, A. (2003), Op. Cit. en LARA, F. (Ed.), p. 84. 
o sobre el arte. Al menos no es solo eso. El mediometraje, con la pintura como punto de partida pero más allá de ella, resulta una reflexión (comparada) sobre el oficio de cineasta y un reconocimiento del mismo en tanto que artista. Dos formas de expresión visuales, dos lenguajes - el de las pinturas de Bouts y el aparato cinematográfico ideado para representarlas - son confrontados. Casi sería mejor escribir que son doblemente confrontados: el lenguaje de la pintura en el del cine y el del cine en la pintura. Al poner en escena una de las obras más famosas de Bouts, precisamente esa «Última cena» central del Retablo del Santo Sacramento, formando con los actores un tableau vivant que busca su reproducción más exacta posible, el cineasta reflexiona sobre los problemas de la representación, de la puesta en imágenes. Delvaux escribe:

era posible, partiendo de Bouts, hacer una reflexión sobre las condiciones de nuestro propio oficio y acerca de la forma en que nosotros concebimos ejercerlo. Y nos dimos cuenta de que Bouts se había planteado, en cierta manera, los mismos problemas que nosotros: cómo poner en escena determinado tipo de acontecimientos; cómo situar en el espacio, por ejemplo, a los doce o catorce personajes de la Cena; cómo se debe manipular un espacio; cómo emplear los colores. (...) El paralelismo entre estas formas de trabajar ha sido nuestro punto de partida. (V.V.A.A., 2001: 6).

Así, la reconstrucción adquiere aquí un valor de modelo; toda escena se corresponde con una mirada y necesita, por lo tanto, la elección previa de un punto de vista. El de Bouts a través de la cámara de Delvaux y Michiels; el de Delvaux y Michiels reflejado en los ojos de Dirk Bouts. Los cineastas se sitúan en el mismo Augenblick (punto de vista) pictórico, sustituyéndolo, convirtiéndose en dobles mismos de Bouts. Una operación - la de la puesta en escena de la «Última cena» - que tiene algo de instante suspendido, de captura del "instante mejor, más significativo, más típico, más pregnate." ${ }^{14} \mathrm{El}$ resultado: "un pintor, un escritor y un cineasta unidos fraternalmente." 15

\section{Un ejemplo de ensayo cinematográfico}

La noción de cine-ensayo, o de ensayo cinematográfico, uno de los modos dentro del cine de no-ficción o documental, como ha señalado Weinrichter (2007), pese a su pujanza en las últimas décadas, es aún un concepto huidizo y al que falta todavía algo de precisión conceptual. En este sentido, Alain Bergala ha señalado que el cine-ensayo "no obedece a ninguna de las reglas que rigen generalmente el cine como institución", ${ }^{16}$ siendo un género libre

14. Aumont, J. (1997), Op. Cit., p. 59.

15. Delvaux, A. (1977/78), Ecriture, peinture, cinéma, Positif, 200/202, Lyon, p. 39.

16. Bergala, A. (2000), Qu'est-ce qu'un film-essai? en Astric, S. (Ed.), Le film-essai: identification d'un genre, París: Bibliothèque du Centre Pompidou, p. 14 
que no se pliega a imperativos y condicionantes ni industriales ni expresivos. Un tipo de film que

debe inventar, cada vez, su propia forma, que solo le valdrá a ella. El documental, generalmente, tiene un tema, es una película "sobre"... Y este tema, por regla general, preexiste como tal en el imaginario colectivo de la época (...) El film-ensayo surge cuando alguien ensaya pensar, con sus propias fuerzas, sin las garantías de un saber previo, de un tema. (Bergala, 2000: 14).

Éste es precisamente el caso de la película de Delvaux, que no solo inventa su misma forma, como veremos más tarde, sino también, a un tiempo, su propio tema. Y es precisamente ahí donde el film se desliga - tanto temática como formalmente - del documental sobre arte anteriormente expuesto. Si la principal búsqueda de Met Dieric Bouts es una reflexión, a través del pintor y sus obras, sobre el oficio de cineasta, ésta se consigue paradójicamente despegándose de la figura de Bouts. En contra de ese paradigma dominante del documental sobre pintura, desafiándolo, el guión de Delvaux y Michiels se libera del segundo nivel de la anécdota argumental, es decir, de cuestiones tales como quién es Bouts, de dónde viene, cuáles fueron sus vivencias, cuál es el contexto histórico de sus pinturas, cuándo fueron pintadas, etc. Se prescinde de lo biográfico en el sentido en que podría hacer uso de ello un historiador del arte, y se busca un nuevo campo de correspondencias y asociaciones entre él y los autores de la película. Una de ellas, como ya he comentado, es Lovaina, un lugar de encuentro más vivencial que físico. Otra, definitiva, es esa comparativa entre los oficios del pintor y del cineasta a partir de determinadas problemáticas comunes surgidas de sus respectivas praxis. Delvaux (y Michiels), sirviéndose de una insólita y compleja suerte de mise en abyme - procedimiento narrativo recurrente en la obra delvauxiana (Borgomano y Nysenholc, 1988) -, la reconstrucción de esa última cena tal y como fue concebida por el pintor, se ponen en su lugar. Mediante ese tableu vivant no solo se reconstruye una sesión de posado (los actores jugando sus roles), si no que ésta se alterna con planos del aparato cinematográfico (los técnicos del equipo, la cámara y su objetivo, el propio Delvaux poniéndola en escena y buscando el ángulo exacto del que se sirvió el pintor) y planos-detalle de la obra de Bouts. Como el «Johannes van Eyck fuit hic» de El matrimonio Arnolfini, la inclusión del propio cineasta, esa imagen en abyme se convierte en "el revés testimonial de la propia representación, haciendo de esta forma explícita la causa que genera la obra". ${ }^{17}$ En la convivencia de esas tres imágenes - armonizadas por

17. Iglesias Santos, D. (2014), La imagen-testigo. Una aproximación a la función narrativa del plano en abyme (tesis doctoral), Barcelona, Tesis doctoral: Universidad Pompeu Fabra, p. 20. [https://repositori.upf.edu/bitstream/handle/10230/23003/TFM_DavidIglesias.pdf?seque nce=1] Documento recuperado el 20/09/2016. 
una banda de sonido en la que escuchamos en todo momento los sonidos de esa reconstrucción filmada -, esa imagen en abyme las aúna en una sola, haciendo explícita la meditación principal del film sobre su propia estructura.

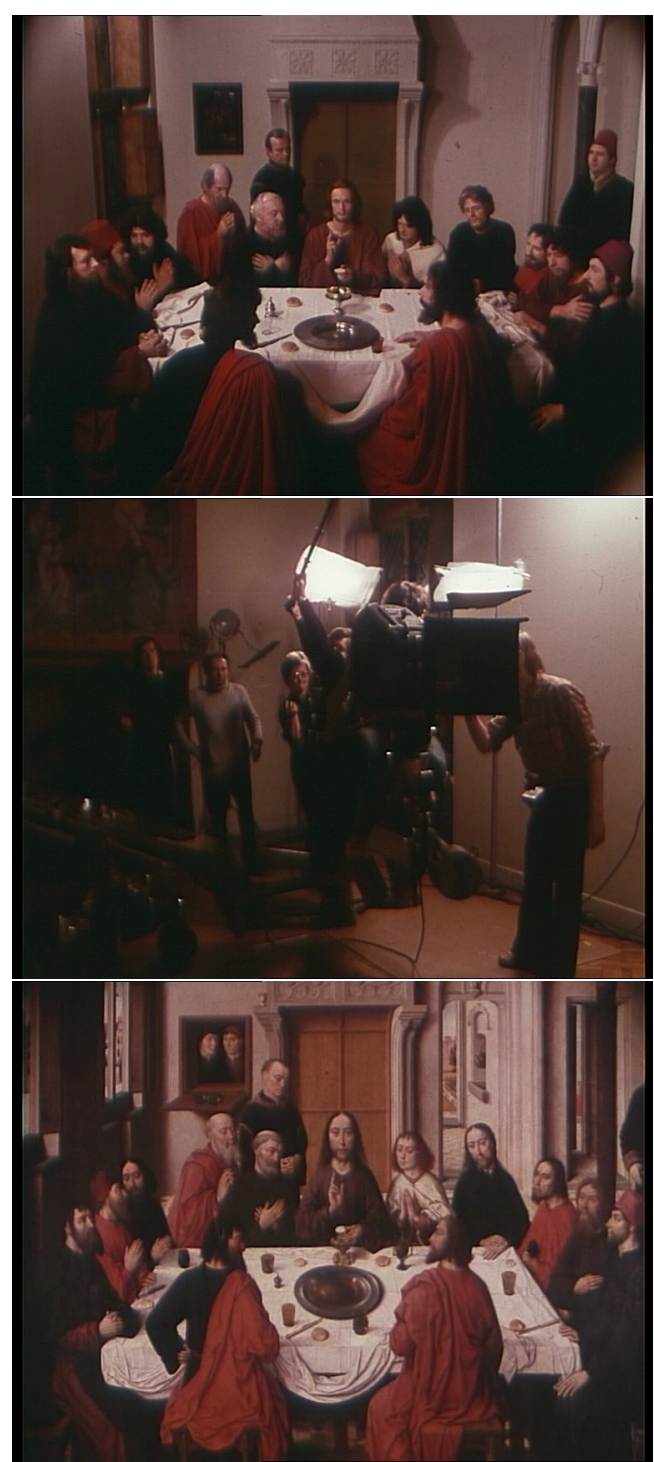

Figs. 3, 4 y 5. La reconstrucción filmada, o un trayecto de la película a la pintura y no a la inversa. 
Como el mismo Delvaux afirmó en el transcurso de una entrevista:

La técnica de la película consiste únicamente en la asociación de imágenes y sonidos, de las imágenes entre ellas, de los sonidos entre ellos, y de imágenes y sonidos entre ellos. Ya no hay lógica narrativa, ya no hay dependencia de ninguna ficción, de ningún orden, sino que la manipulación de todo este material conjunto construye la película, de la misma manera que la manipulación de colores, de formas y de líneas en el espacio constituía para Bouts la obra pictórica. (V.V.A.A., 2001: 6).

$\mathrm{Y}$ es que la dialéctica de los materiales (filmaciones originales, fragmentos de una especie de diario fílmico, filmaciones de cuadros y elementos pictóricos, puesta en imágenes de los mismos a través del tableu vivant), según Weinrichter la expresión más propia del principio básico ensayístico - lo que él mismo denomina un "montaje de proposiciones" (Weinrichter, 2007: 28) -, es el modo elegido por Delvaux y Michiels de cara a conseguir visualizar toda una serie de conceptos intelectuales a través de imágenes y sonidos. Un trabajo y una investigación en torno a las posibilidades representativas y expresivas del cine de no-ficción que continuará en películas-ensayo como To Woody Allen from Europe with love y Babel Opera ou La répétition de Don Juan.

\section{A la búsqueda de un contrapunto cinematográfico}

Lo cierto es que esa técnica resulta un poco más compleja de lo que el propio cineasta admite. $\mathrm{Y}$ en ella juega un papel decisivo, como en algunos de sus filmes de ficción, la noción musical de contrapunto.

Con cierta seguridad gracias a su amplia formación musical (Rubín de Celis, 2008: 39), marcado también de forma decisiva por sus experiencias acompañando musicalmente en vivo la proyección de películas mudas - "acompañé muchas veces al piano Metrópolis, obras de Murnau y de Sjöstrom (...) Así entré en el cine." ${ }^{18}$-, le permitió a Delvaux apreciar el firme contacto existente entre los lenguajes musical y cinematográfico. Incluso antes de iniciarse en su práctica. Los dos persiguen el dominio y un control del tiempo. ${ }^{19}$ Una afinidad que se dedicó a indagar a lo largo de una filmografía entendida siempre como una búsqueda, o una investigación, de los límites del lenguaje cinematográfico. El cine de Delvaux surge de una concepción no ya musical - como se ha escrito a menudo, incluyéndome a mí - sino sonora, que forma parte de un planteamiento experimental mayor, por expresarlo de algún modo, de la praxis cinematográfica: "Decir que el sonido es tan importante como la

18. Delvaux, A. (2003), El dominio del tiempo. En Lara, F. (Ed.) Op. cit., p. 76.

19. Como afirma Michel Chion, "es al sonido sincrónico al que debemos el haber hecho del cine un arte del tiempo" (Chion, 1993: 22). 
imagen es decir muy poco. En el mundo sonoro creo que hay infinitamente más cosas para hallar que en el de la imagen". ${ }^{20}$ Una concepción tan patente en sus primeras películas de ficción, como Una noche, un tren o Belle, surgidas musicalmente en su estructura, como en sus posteriores ensayos cinematográficos. En Cita en Bray, construida estructuralmente a partir de la forma del rondó (A, B, A, C, A...), basada en "un tema principal que reaparece y se alterna con diferentes temas intermedios", ${ }^{21}$ que da paso a la construcción a partir de la irrupción del pasado (a través de numerosos flash-backs) en el presente. Y muy notablemente, desde luego, en el caso de Met Dieric Bouts, que sigue un esquema de construcción derivado de las estructuras rítmicas de las obras de Guillame Dufay y Guillame de Machault. En composiciones como motetes, ballades, rondeux y virelais, de gran influencia en la música medieval posterior y que muestran con claridad las tendencias del Ars nova, ambos desarrollaron formes fixes en las que el texto y la música poseen unos patrones de repetición concretos, determinados por el género poético correspondiente. Así, Hoppin ${ }^{22}$ y Grout y Palisca ${ }^{23}$ proponen las siguientes fórmulas musicales para ballades (aabC, donde $\mathrm{C}$ representa el estribillo), rondeaux (АВaAabAB) y virelais (Abba...A, donde A representa el estribillo; b, la primera parte de la estrofa, que se repite; y a, la última, que lleva la misma melodía del estribillo). Formas contrapuntadas que sirven de inspiración estructural para el texto y las imágenes de Michiels y Delvaux. "Decidí organizar - escribe este último una estructura rítmica, como hacen muchos músicos, y completarla después con imágenes que iría seleccionando". ${ }^{24}$

Dentro de la concepción sonora por parte del cineasta flamenco de la praxis del cine, no solo los diálogos y la música resultan categóricos. Todos los sonidos comparten su importancia. Es absolutamente necesario que "los ruidos lleguen a ser música" 25 - según refleja la nota bressoniana - y que esta "música", conformada por todos los elementos de la banda de sonido (incluido el uso del silencio o la supresión de la misma), jamás entendida como acompañamiento, como sostén o refuerzo, sino como un principio compositivo más, se equipare a la primacía de las imágenes, acabando con su hegemonía. El uso combinado de imágenes y sonidos, más allá de su valor añadido (Chion, 1993: 13) o de

20. Aprà A., Comolli, J-L., y Narboni, J. (1971), Conversación con André Delvaux, Film Ideal: 222-223, Madrid, p. 244.

21. Grabner, H. (2001), Teoría general de la música, Madrid: Akal, pp. 197-198.

22. Hoppin, R. H. (1991), "El Ars Nova en Francia" y "Guillaume de Machaut" en La música medieval, Madrid: Akal, pp. 369446.

23. Grout, D. \& Palisca, C. (2001), "La música francesa e italiana del siglo XIV" en Historia de la música occidental, Vol. 1 Madrid: Alianza Música, pp. 145157.

24. Delvaux, A. (2003), El dominio del tiempo. En Lara, F. (Ed.) Op. cit., p. 79.

25. Bresson, R. (1979), Notas sobre el cinematógrafo, México DF: Ediciones Era, p. 25. 
lo puramente descriptivo, aproxima a Delvaux a la sensibilidad, los principios e ideales del Simbolismo, "alerta a posibilidades de efectos sinestesícos, a simetrías inquietantes, correspondencias intrincadas, a ritmos y rimas". ${ }^{26}$ Con anterioridad a su actividad cinematográfica, el autor de El hombre del cráneo rasurado cursó, como complemento a sus estudios avanzados de composición y de piano, las materias de contrapunto y fuga con el maestro Francis de Bourguignon en el Conservatorio Real de Bruselas. Ambas técnicas compositivas tratan por igual de la relación existente entre dos o más voces independientes - polifonía - con la finalidad de obtener un determinado equilibrio armónico. Dado que Delvaux concibió siempre la música como un arte capaz de proporcionar formas y estructuras a las otras artes (notablemente al cine), resulta bastante lógico que, en sus películas, experimentase con las posibilidades estructurales derivadas de formas musicales como la alternada del rondó - para la construcción quebrada a partir de flash-backs en Una noche, un tren y la ya citada de Cita en Bray - o la superposición de voces/líneas instrumentales de la fuga - muy notablemente en la película que nos ocupa -. En ambos casos, se trata de desarrollar una estructura con una lógica, una construcción y un desarrollo propios, basada en un sistema de repetición-variación.

Al no existir en Met Dieric Bouts ese hilo de ficción, ese segundo nivel argumental anteriormente mencionado, que imponga unas exigencias narrativas determinadas así como una temporalidad asociada a éstas, la banda de sonido se erige en la principal herramienta de construcción (y de cohesión) del conjunto del film. Todas sus imágenes diversas, reales o pintadas, se funden entre sí merced no tanto al montaje, que las amalgama, sí, como a la edición de la banda de sonido que crea insospechadas rimas, correspondencias y uniones, analogías y contraseñas que reaparecen de cuando en cuando en los diálogos, en las voces, en los sonidos que se escuchan. Diálogos que se dirían rimados, pautados, como si consistieran en la letra de la melodía a la que acompañan, con esos leit motiv repetidos incesantemente: «Nuestro Ayuntamiento», «nuestros mercados», «nuestros muertos», «nuestros...». Ahí es donde el contrapunto hace su trabajo, recubriendo con su ropaje melodioso un catálogo dispar de elementos audiovisuales a los que aporta un equilibrio armónico tan personal como novedoso. En un momento determinado, ante la visión de una campiña en Lovaina, una música - cuya partitura vemos representada gráficamente en la imagen - suena asociada con los diálogos y los ruidos provenientes de esos mismos campos por los que deambuló el pintor cinco siglos atrás y que reaparecen una y otra vez como fondo de sus telas. La disparidad cede su lugar

26. Mosley, P. (2004), The Man Who Had His Hair Cut Short. En Mathjis E. (Ed.), The cinema of the Low Countries, Londres: Wallflower, p. 81. 
a la armonía. Todo es uno. Un trabajo polifónico de composición que ejemplifica paradigmáticamente esa forma de contrapunto cinematográfico. Modélico igualmente en la escena en la que se confrontan el día de mercado y la celebración fúnebre de Todos los Santos en esa pequeña localidad norteña del país.

\section{Conclusiones}

Met Dieric Bouts resulta, por la suma de sus búsquedas audiovisuales anteriormente expuestas, que abundan en un género "libre" como el cine-ensayo, superando el paradigma dominante hasta entonces del documental sobre pintura, quizás la más sistemática y personal de todas las obras del cineasta. Seguramente la más abstracta y experimental narrativa y estructuralmente. Siendo una suerte de conversación de los autores con el pintor Dirk Bouts, conversación que les acerca a unos y a otro a partir de la práctica de sus respectivos oficios, la película combina libremente la imagen - real y pintada - con los tres elementos propios de la banda de sonido en una forma que podríamos denominar una "organización musical" del film, que constituye un ejercicio singular de contrapunto cinematográfico. Una sistematización formal que, si bien estará presente en los posteriores trabajos de Delvaux, no alcanzará una perfección que, en este caso, tiene algo de modélico.

\section{Referencias bibliográficas}

Aprà, A.; Comolli, J.-L. \& Narboni, J. (1971). Conversación con André Delvaux. Film Ideal: 222-223. Madrid.

Aumont, J. (1997). El ojo interminable. Cine y pintura. Barcelona: Paidós.

Bazin, A. (1990). ¿Qué es el cine?. Madrid: Rialp.

Bonitzer, P. (2007). Desencuadres: cine y pintura. Buenos Aires: Santiago Arcos Editor.

Borgomano, L. \& Nysenholc, A. (1988). André Delvaux. Une æeuvre, un film: L'Euvre au noir. Klincksieck: Éditions Labor-Méridiens.

Bresson, R. (1979). Notas sobre el cinematógrafo. México DF: Ediciones Era.

Brumagne, M.-M. (1977). Franju. Impressions et aveux. Lausana : L'Age d'Homme.

Chion, M. (1993). La audiovisión. Introducción a un análisis conjunto de la imagen y el sonido. Barcelona: Paidos.

Delvaux, A. (1977/78). Ecriture, peinture, cinema. Positif: 200-202. Lyon. 
Delvaux, A. (2003). El dominio del tiempo. In F. Lara (ed.), Doce miradas sobre el cine europeo (el autor y su obra) (pp. 74-81). Valladolid: Junta de Castilla y León.

Delvaux, A. (2003). Un trayecto de cineasta. In F. Lara (ed.), Doce miradas sobre el cine europeo (el autor y su obra) (pp. 82-90). Valladolid: Junta de Castilla y León.

Grabner, H. (2001). Teoría general de la música. Madrid: Akal.

Grout, D. \& Palisca, C. (2001). La música francesa e italiana del siglo XIV. In V.V.A.A., Historia de la música occidental, vol. 1. Madrid: Alianza Música.

Hoppin, Richard H. (1991). El Ars Nova en Francia y Guillaume de Machaut. In V.V.A.A., La música medieval. Madrid: Akal.

Iglesias Santos, D. (2014). La imagen-testigo. Una aproximación a la función narrativa del plano en abyme. Barcelona, Tesis doctoral: Universidad Pompeu Fabra [https://repositori.upf.edu/bitstream/handle/10230/23003/ TFM_DavidIglesias.pdf?sequence=1] Documento recuperado el 20/09/ 2016.

Mosley, P. (2004). The man who had his hair cut short. In E. Mathjis (ed), The cinema of the Low Countries (pp. 77-85). Londres: Wallflower.

Rubín de Celis Pastor, S. (2008). El realismo mágico en la obra cinematográfica de André Delvaux, Madrid, Tesis doctoral: Universidad Complutense de Madrid [http://eprints.ucm.es/8147/1/T30498.pdf] Documento recuperado el 09/10/2016.

Sánchez-Biosca, V. (s.d.). Cine y vanguardias artísticas.

Sojcher, F. (2005). André Delvaux, le cinéma ou l'art des rencontres. París : Seuil/Archimbaud.

V.V.A.A. (2001). André Delvaux. Madrid: Filmoteca Española.

Weinrichter, A. (ed.) (2007). Tentativas en torno al cine-ensayo. Pamplona. Gobierno de Navarra. 